The two members are Lord Casey, who recently resigned from Parliament on his elevation to the peerage, and Mr. E. P. S. Roberts, a prominent Queensland grazier. Lord Casey's association with C.S.I.R.O. dates back to 1937, when he first became minister-in-charge of the Council for Scientific and Industrial Research. Mr. Roberts, who is aged fortysix, has been associated with C.S.I.R.O. as a member of its Advisory Council since 1957. After the War, he purchased his own property at Toobeah, in Queensland, and became interested in the wider problems of the pastoral industries. His appointment will ensure that the point of view of the man on the land and the problems of northern Australia are kept constantly before the Executive.

\section{Iron and Steel Institute: Awards}

The Council of the Iron and Steel Institute has announced the award of the following medals and prizes : Bessemer Gold Medal for 1960: Prof. Hermann Schenck, director of the Institut für Eisenhüttenwesen, Rheinische-Westfälische Technische Hochschule, Aachen, Germany, and president of the Verein deutscher Eisenhüttenleute; Sir Robert Hadfield Medal for 1960 : Dr. J. C. Hudson, head of the Corrosion Section, Chemistry Department, British Iron and Steel Research Association; Andrew Carnegie Silver Medal for 1959 : Dr. P. R. V. Evans, Research Department, Metropolitan-Vickers Electrical Co., Ltd., Manchester, for a, paper on "The Effect of Rolling Unstable Austenitic 0.76\% Carbon Steel at $220-300^{\circ}$ C." (Journal, January 1959, p. 34) ; his co-author, Prof. Hugh O'Neill, was not eligible for an award; William Prize for 1959 : Mr. I. M. D. Halliday, Research and Development Department, The United Steel Companies, Ltd., Rotherham, for a paper on "Continuous Casting at Barrow" (Journal, February 1959, p. 121).

Mr. W. F. Cartwright, assistant managing director of the Steel Company of Wales, Ltd., since 1954, has been elected president of the Iron and Steel Institute for 1960-61.

\section{Cost of the Radio Telescope at Jodrell Bank}

Is a written answer in the House of Commons on March 24, Sir David Eccles, as representing the Minister for Science, stated that there is nothing owing on the capital cost of the radio telescope at Jodrell Bank, and that the Government is not prepared to increase its contribution. The Government has already contributed substantially to the cost of upkeep of the telescope and any applications which might be made for further grants for research involving its use would continue to be dealt with on their merits by the Department of Scientific and Industrial Research. In oral replies Sir David said that the United States Government has already paid in full for work undertaken on its behalf with the radio telescope. Treasury approval for the final $£ 130,000$ of the total grant of $£ 360,000$ towards the capital cost of construction of the radio telescope was given on August 8, 1956, and payment to the University completed on March 17, 1958. Three further grants of $£ 13,000$ annually for 4 years, for running costs, $£ 60,820$ for development of new apparatus and techniques, and of $£ 15,200$ for galactic and extra-galactic neutral hydrogen emission studies and development of data-handling processes have been authorized. Sir David said he was not aware of any delay on the part of the Treasury in giving approval or by the Department of Scientific and Industrial Research in making the payments to the University. There was a sum of $£ 60,000$ left to be colleeted by the University of Manchester towards the capital cost and, referring to an appeal to the Government to subscribe this final sum, Sir David said that Lord Hailsham considers that the Government's contribution is sufficient and that it is well understood that the rest of the money will be raised by the University.

\section{City and Guilds of London Institute Fellowships}

THE Fellowship of the City and Guilds of London Institute has been conferred upon the following past students in recognition of their contributions to industry or the professions in which they are engaged: J. J. Gracie (director and general manager of the G.E.C. Engineering Works at Witton, Birmingham); C. G. Hawes (consultant in hydrology and irrigation); T. M. Malkani (chief engineer of Calcutta Port Commissioners) ; H. D. Morgan (senior partner of Sir William Halcrow and Partners); D. W. Morphy (joint managing director of Morphy-Richards, Ltd.); and A. W. Skempton (professor of civil engineering, City and Guilds College, Imperial College of Science and Technology). The Council of the City and Guilds of London Institute has also conferred the fellow. ship of the Institute, honoris causa, upon : Sir Willis Jackson (president of the Institution of Electrical Engineers, director of research and education, A.E.I. (Manchester), Ltd.); Prof. D. M. Newitt (pro-rector of the Imperial College of Science and Technology), head of the Department and Courtauld Professor of Chemical Engineering).

\section{Joint U.S.-Canadian Satellite Project}

Durive April 1959, Dr. A. Hartley Zimmerman. chairman of the Canadian Defence Research Board. and Dr. T. Keith Glennan, administrator of the U.S. National Aeronautics and Space Administration, announced acceptance by the Administration of a proposal by the Defence Research Telecommunications Establishment for a joint satellite experiment. Initially, it was proposed that the satellite will be constructed and instrumented by the Defence Research Telecommunications Establishment and launched late in 1961 at Vandenberg Air Force Base by means of a three-stage Thor-Delta rocket provided by the Administration. The experiment will be designed to achieve two objectives. First, to examine and record information about the structure of upper levels of the ionosphere by using a radio sounder above the ionized layers. Secondly, to provide information about the radio signals which emanate from outer space. The satellite will be launched in a near-polar orbit, and for protection during its acceleration through the dense atmosphere, it will be enclosed in a metal nosecap or shroud. On reaching orbit altitude of 700 miles, both the nosecap and the third-stage rocket will be separated from the satellite. The Defence Research Telecommunications Establishment will operate four receiving stations in Canada. It is hoped that the satellite will continue to transmit data for about a year following the launching. The information is to be exchanged freely with other nations through the Committee on Space Research of the International Council of Scientific Unions.

Factories (lonizing Radiations) Special Regulations A REVISED draft code (Ministry of Labour. Factories Acts, 1937 and 1948. Factories-(Ionizing 